\title{
Yield, growth and quality of summer sesame (Sesamum indicum L.) as influenced by irrigation and nitrogen levels
}

\author{
RUPALI R. DAMDAR*, V.M. BHALE AND K.M. DESHMUKH \\ Department of Agronomy, Dr. Panjabrao Deshmukh Krishi Vidyapeeth, AKOLA(M.S.) INDIA \\ (Email : rupalid282@gmail.com)
}

\begin{abstract}
A field study aimed to evolve efficient and economically viable irrigation schedule and nitrogen management for improving quality, yield and growth of summer sesame var. AKT 101 was conducted at Agronomy Department Farm, Dr. Panjabrao Deshmukh Krishi Vidyapeeth, Akola, during summer season of 2012. Experimental results revealed that growth characters, yield contributing characters and quality significantly higher with irrigation scheduling at 1.0 IW/CPE (Irrigation water amount/ Cumulative pan evaporation) and nitrogen application at $90 \mathrm{~kg} \mathrm{~N} \mathrm{ha}^{-1}$. Similarly, treatment $1.0 \mathrm{IW} / \mathrm{CPE}$ combined with nitrogen application at $90 \mathrm{~kg} \mathrm{~N} \mathrm{ha}^{-1}$ recorded significantly highest seed yield and oil yield $\left(\mathrm{kg} \mathrm{ha}^{-1}\right)$ over rest of the combinations and significantly lowest was observed in irrigation scheduling at $0.4 \mathrm{IW} / \mathrm{CPE}$ combined with treatment $30 \mathrm{~kg} \mathrm{~N} \mathrm{ha}^{-1}$.
\end{abstract}

Key Words : Irrigation, IW/CPE, Quality, Sesame, Yield

View Point Article : Damdar, Rupali R., Bhale, V.M. and Deshmukh, K.M. (2015). Yield, growth and quality of summer sesame (Sesamum indicum L.) as influenced by irrigation and nitrogen levels. Internat. J. agric. Sci., 11 (2) : 301-306.

Article History : Received : 08.04.2015; Revised : 24.05.2015; Accepted : 31.05 .2015

\footnotetext{
* Author for correspondence
} 